\title{
Elective Laparoscopic Ovariectomy in Domestic Swine (Sus scrofa domesticus)
}

\author{
Manoela Giovanna Sinhorelli', Luciana Branquinho Queiroga², Vanessa Souza Müller², \\ Gabriela Friedrich Lobo D'Avila², Lívia Eichenberg Surita ${ }^{3} \&$ Carlos Afonso de Castro Beck'
}

\begin{abstract}
Background: In the last years the number of exotic company animals has been increased, and the demand for neutering services for these animals has become greater. By the author's knowledge, there are no records of elective ovariectomy in domestic swine (Sus scrofa domesticus). The current paper reports a case of elective laparoscopic ovariectomy in a domestic swine (Sus scrofa domesticus).

Case: A 4-month-old domestic swine (Sus scrofa domesticus), weighing $45 \mathrm{~kg}$ was referred to elective video-laparoscopic ovariectomy at the Veterinary Clinics Hospital of the Federal University of Rio Grande do Sul (HCV - UFRGS). Physical examination and laboratory tests, including hemogram and biochemistry (alanine aminotransferase - ALT, serum albu$\mathrm{min}$ and creatinine), were within normal range for the species. Ketamine hydrochloride (Cetamin $\left.{ }^{\circledR}\right) 10 \mathrm{mg} \cdot \mathrm{kg}^{-1}$, xylazine hydrochloride $\left(X_{\text {Xilazin }}{ }^{\circledR}\right) 2 \mathrm{mg} \cdot \mathrm{kg}^{-1}$, and midazolam $\left(\right.$ Midazolam $\left.^{\circledR}\right) 0.5 \mathrm{mg} \cdot \mathrm{kg}^{-1}$ were administered intramuscularly (IM) as pre-anesthetic medication. The anesthetic induction was performed with intravenous (IV) propofol (Propovan ${ }^{\circledR}$ ) and anesthesia was maintained with isoflurane (Isoforine ${ }^{\circledR}$ ) diluted in $\mathrm{O}_{2}$ by a universal vaporizer with a partial gas rebreathing anesthetic system. Throughout the procedure, were monitoring constantly the invasive blood pressure (IBP), electrocardiogram (ECG) in lead II, peripheral arterial saturation with $\mathrm{O}_{2}\left(\mathrm{SpO}_{2}\right)$, end-tidal carbon dioxide concentration $\left(\mathrm{ETCO}_{2}\right)$, and esophageal temperature. The abdominal cavity was accessed through the insertion of three portals (one of $10 \mathrm{~mm}$ of diameter and other two of $5 \mathrm{~mm}$ of diameter). The cavity was inflated with medicinal $\mathrm{CO}_{2}$ until the pressure of $10 \mathrm{mmHg}$ was achieved. The uterine body and ovaries were identified. The right ovary was suspended and, by a bipolar clamp, the ovarian vessels were occluded through electrocoagulation in three distinct locations with approximately $0,5 \mathrm{~cm}$ between themselves, and cut off. The right ovary was removed from the cavity. An identic maneuver was used for the realization of the surgical steps and removal of the left ovary. By the end, the cavity was deflated and the cannulas were removed. The abdominal wall was sutured with Sultan pattern with 3-0 polyglycolic acid thread, and the skin was sutured with simple interrupted suture with 3-0 nylon monofilament. The post-operative evaluations were subjective and fitting with the patient's behavior. The patient didn't show any clinical signs of pain, discomfort and returned to its usual eating habits on the second day after the procedure. No signs of infection, dehiscence, cicatrization retard or other complications were observed in the surgical wound. The stitches were removed after seven days.

Discussion: This case report shows the applicability of the video-laparoscopic ovariectomy technique by three portals in other species than dogs and cats, and serves as bibliographic support to the veterinary endosurgery field. Based on previous studies, it has been concluded that minimally invasive procedures represent the most beneficial sterilization methods to the patient due to its diagnostical and surgical capacity, as well as minor surgical trauma and shorter recovery time. The most common indication for the video-laparoscopic technique in veterinary routine is the elective sterilization. Pyometra, urinary incontinence and weight gain are complications that are not diagnosed more frequently after ovariectomy when compared to ovariohysterectomy. The laparoscopic ovariectomy is a viable technique to be applied to the swine, with the most difficult aspect being the anatomical peculiarities of the animal.
\end{abstract}

Keywords: neutering, three portals, endosurgery. 


\section{INTRODUCTION}

Elective neutering of bitches and cats is one of the most accomplished surgeries in veterinary medicine [8]. It is performed by removing the ovaries and uterus (ovariohysterectomy - $\mathrm{OVH}$ ) or by removing only the ovaries (ovariectomy - OVE) [4]. To the author's knolodge, there are no reports of elective ovariectomy in domestic swine (Sus scrofa domesticus). Although it is not a routine surgery in domestic swine, the search for this procedure tend to increase as the interest of these animals as pets becomes popular. Considering the peculiarities of the swine anatomy, the description of the minimally invasive surgical technique for swine is extremely important to provide a bibliographic source to the veterinary endosurgery field. At five or six months of age, swine females enter puberty, implying several behavioral and physiological changes. After puberty, the main behavioral changes perceived in estrus are related to restlessness, reflex of immobilization and acceptance to mounts. Physiological changes are noticed with occasional vaginal mucus discharge, vulvar edema and hyperemia [9]. Those are reasonable reasons for the indication of elective neutering of these animals when they are kept as pets. Due to the diagnostic and surgical capacity, in addition to conferring minor surgical trauma and shorter recovery time, videolaparoscopy has gained great space in veterinary medicine [15].

The objective of this paper is to describe the access and the video-laparoscopic technique for ovariectomy in domestic swine.

\section{CASE}

A domestic swine (Sus scrofa domesticus), 4-month-old, weighing $45 \mathrm{~kg}$, was referred to videolaparoscopic elective OVE at the Veterinary Clinics Hospital of the Federal University of Rio Grande do Sul (HCV - UFRGS). Physical examination and laboratory tests, including hemogram and biochemistry (alanine aminotransferase - ALT, serum albumin and creatinine), were within normal range for the species.

Ketamine hydrochloride $\left(\operatorname{Cetamin}^{\circledR}\right)^{1} 10$ mg.kg-1 ${ }^{-1}$ xylazine hydrochloride $\left(\text { Xilazin }^{\circledR}\right)^{1} 2$ mg.kg ${ }^{-1}$, and midazolam $\left(\text { Midazolam }{ }^{\circledR}\right)^{2} 0.5$ mg. $\mathrm{kg}^{-1}$ were administered intramuscularly (IM) as pre-anesthetic medication. After $15 \mathrm{~min}$, tricotomy of the ventral abdominal region was performed. Catheterization of the external auricular artery and cephalic vein were performed. Pre oxygenation with $100 \% \mathrm{O}_{2}$ was provided by mask. The anesthetic induction was performed with intravenous (IV) propofol (Propovan $\left.{ }^{\circledR}\right)^{3}$ until there were relaxation of the mandible and absence of protective reflexes. Orotracheal intubation was performed with a cuffed tube number 7.5. Anesthesia was maintained with isoflurane (Isoforine $\left.{ }^{\circledR}\right)^{3}$ diluted in $\mathrm{O}_{2}$ by a universal vaporizer with a partial gas rebreathing anesthetic system. Sodium ampicillin (Ampicilina Veterinária Injetável $200 \mathrm{mg} / \mathrm{mL}$ ) 22 mg.kg-1 IV was administered as prophylactic antibiotic. Throughout the procedure, were monitoring constantly the invasive blood pressure (IBP), electrocardiogram (ECG) in lead II, peripheral arterial saturation with $\mathrm{O}_{2}\left(\mathrm{SpO}_{2}\right)$, end-tidal carbon dioxide concentration $\left(\mathrm{ETCO}_{2}\right)$, and esophageal temperature. GE Dash $4000^{\circledR 6}$ multi-parameter monitor was used. For intraoperative analgesia, fentanil $\left(\text { Fentanest }^{\circledR}\right)^{3} 5$ $\mu \mathrm{g} . \mathrm{kg}^{-1}, \mathrm{IV}$ was administered whenever the mean arterial pressure was greater than $90 \mathrm{mmHg}$. Mechanical ventilation was limited to pressure. Respiratory rate (RR) and peak inspiratory pressure were adjusted to maintain $\mathrm{ETCO}_{2}$ between 35 and $45 \mathrm{mmHg}$. The swine was placed in dorsal decubitus, with the head directed in the opposite direction to the tower that contained the video-surgery equipment. Antisepsis of the surgical area was performed with alcohol-iodine-alcohol. Three access portals were inserted. The first portal of $10 \mathrm{~mm}$ and $\varnothing$ was positioned in the ventral midline, cranial to the umbilical scar, and a $10 \mathrm{~mm}$ and $\varnothing$ camera was inserted through it. The second and the third portals, both of $5 \mathrm{~mm}$ and $\varnothing$, were placed to the right and left of the first portal, respectively. The pneumoperitoneum was achieved by insufflation of the abdominal cavity with $\mathrm{CO}_{2}$ until the pressure of $10 \mathrm{mmHg}$. During the initial exploration of the abdominal cavity, urinary bladder repletion was observed and video-assisted cystocentesis was performed to facilitate the visualization of intracavitary structures. The uterine horns were then identified. The right ovary was identified by the right uterine horn suspension maneuver. The right ovary was suspended to promoting its distance from intestinal loops and other intracavitary structures. With the aid of a bipolar forceps, the ovarian vasculature was occluded through electrocoagulation in three distinct locations approximately $0.5 \mathrm{~cm}$ apart (Figure 1). The vasculature was then sectioned between the second and third occluded sites, preserving two points cau- 
terized in the remaining pedicle (Figure 2). The right ovary was removed from the cavity using a Maryland forceps and a diameter reducer adapted to the second trocar. Identical surgical maneuvers were adopted for the cauterization, resection, and removal of the left ovary. During the electrocoagulation of the ovarian vasculature on the right ovary, it was possible to notice a slight change in coloration (from rosy to purplish) at the end of the corresponding uterine horn. This fact did not implicate any type of complication in the postoperative period. The cavity was deflated and the portals removed. The abdominal wall was sutured with Sultan standard with 3-0 polyglycolic acid thread. The skin was sutured with simple interrupted suture with 3-0 nylon monofilament. At the end of the procedure the patient presented hyperthermia $\left(40.7^{\circ} \mathrm{C}\right)$, requiring the use of ice packs to normalize their body temperature. Meloxicam (Maxicam $\left.{ }^{\circledR} 2 \%\right)^{5} 0.2$ mg. $\mathrm{kg}^{-1}$ and sodium ampicillin (Ampicilina Veterinária Injetável $200 \mathrm{mg}$ / $\mathrm{mL})^{4} 22 \mathrm{mg} \cdot \mathrm{kg}^{-1}$, IV were administered immediately before the close of the abdominal cavity. The swine only presented total anesthetic recovery in 24 hours, which can be considered a prolonged recovery time. The postoperative evaluations were subjective according to the behavior of the patient. The swine did not show clinical signs of pain or discomfort and resumed usual eating habits on the second postoperative day. Infection, dehiscence, delay in healing or other complications related to surgical wound were not observed in the present report. The skin sutures were removed in seven days.

\section{DISCUSSION}

Despite that laparoscopic OVE offers a safe technique for neutering of dogs and cats, and be widely held in Europe and North America, it is not very popular among Brazilian veterinarians. In addition, laparoscopic OVE is faster than others laparoscopic $\mathrm{OVH}$ techniques [3]. This method comprises the principle of triangulation between the trocars and access to or near the umbilical scar [16]. The most common indication for this technique is elective neutering. It is less frequently employed in the treatment of uterine and / or ovarian conditions [5]. Pyometra, urinary incontinence, and weight gain are not most frequently diagnosed after OVE, when compared to OVH [18]. Minimally invasive surgical techniques may be an alternative to surgical procedures performed by laparo- tomy in order to minimize perioperative complications such tissue trauma, pain in the postoperative period, and hospitalization time [14]. Complications associated with $\mathrm{OVH}$ and laparoscopic $\mathrm{OVH}$ include reproductive tract bleeding, organ laceration, and incision problems such as edema, flushing, and suture dehiscence [17]. A disadvantage of laparoscopic surgery is the inability to receive adequate tactile feedback, which can result in the use of exuberant force during manipulation or tissue [12], but such complications were not observed during the surgical procedure.

Unlike bitches and female cats, in which the ovaries remain in the dorsal part of the abdomen and caudal to the kidneys, the ovaries of the female pigs descend to the middle of the abdomen. The uterus of the domestic swine is composed of a long neck, a short body and markedly long horns, suspended by extensive broad ligaments. The horns and ovaries are extremely mobile, making it impossible to delimit an exact position in the abdominal cavity [11].

Due to surgical inexperience of the surgical team in operating this species, and to the anatomical peculiarities of the domestic swine, the surgery time was $100 \mathrm{~min}$. This time was longer than previously reported for three portals videolaparoscopic OVE in felines ( $25 \mathrm{~min} 33 \mathrm{~s} \pm 7 \mathrm{~min} 01 \mathrm{~s}$ ) and in canines (50 $\min 07 \mathrm{~s} \pm 16 \min 02 \mathrm{~s}$ ) [6]. Possibly, this time should be reduced as the surgical team performs more surgeries in swine. Occlusion of the ovarian vasculature is commonly performed by techniques with bipolar electrocautery, titanium clips, ligature with suture wire, and vascular stapler [7]. Electrocoagulation is recommended when the pedicle is friable or vascular because, compared to the aforementioned techniques, it reduces the risk of damage to these structures [10]. In other study monopolar and bipolar coagulation in laparoscopic OVE for canines was compared, and monopolar electrocoagulation was associated with an increased risk of intraoperative hemorrhage [17]. The use of bipolar electrocautery in this case presented excellent occlusion of the ovarian vasculature with no evidence of hemorrhage. The pneumoperitoneum pressure chosen $(10 \mathrm{mmHg})$ did not show changes in respiratory patterns [13]. That pressure allows adequate space for the handling of the surgical instruments and visualization of the cavity, ovaries, and other structures. The visualization is also benefited by the magnification of the image generated by the endoscope [2]. 


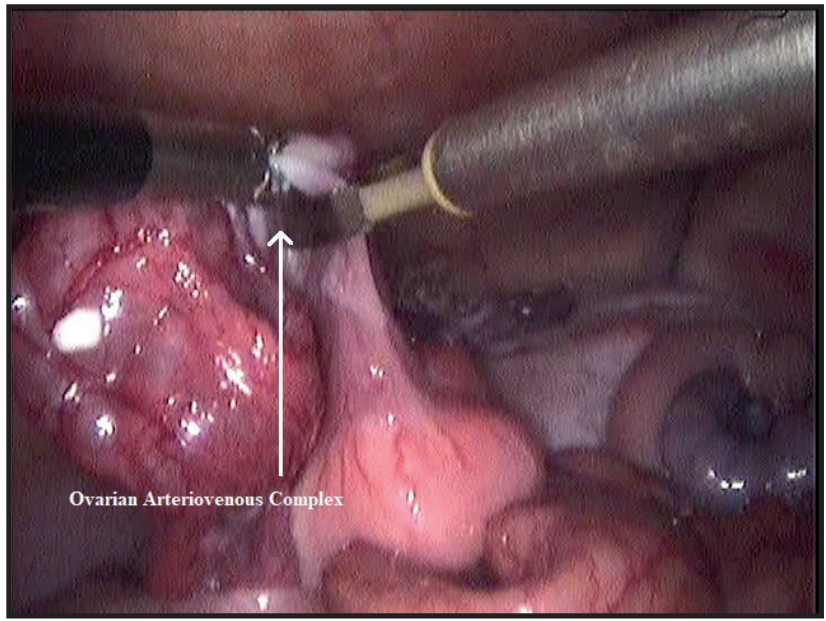

Figure 1. Ovarian arteriovenous complex cauterization by bipolar forceps in domestic swine (Sus scrofa domesticus) submitted to elective laparoscopic ovariectomy.

The first symptoms of malignant hyperthermia include tachycardia, hyperventilation, localized muscular stiffness, cyanosis, arrhythmia, excessive sweating, and hyperthermia [1]. The hyperthermia that was showed by the patient by the end of surgery was not characterized as malignant hyperthermia, once the $\mathrm{CO}_{2}$ levels remained in physiological range. The hyperthermia presented by the patient was associated with the high temperatures of the environment.

In this case, laparoscopic ovariectomy proved to be a viable technique to be performed on a swine female. The main difficulty of execution was the more centralized positioning of the uterine and ovarian

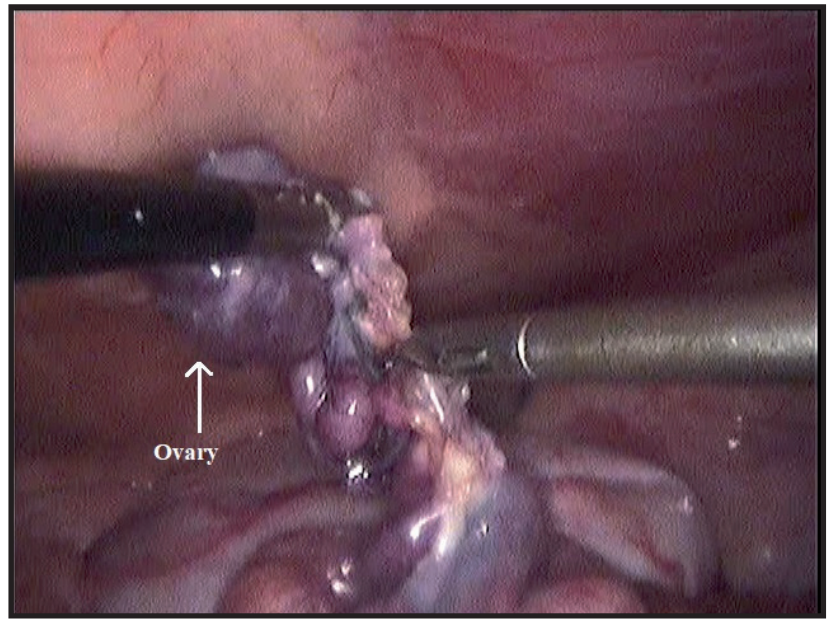

Figure 2. Ovarian vessels section preserving two cauterization points in the remaining pedicle in domestic swine (Sus scrofa domesticus) submitted to elective laparoscopic ovariectomy.

horns, which limits a more favorable pedicle exposure when compared to the female cats and bitches.

\section{MANUFACTURERS}

${ }^{1}$ Syntec do Brasil. Cotia, SP, Brazil

${ }^{2}$ Hipolabor Farmacêutica Ltda. Sabará, MG, Brazil.

${ }^{3}$ Cristália Produtos Químicos Farmacêuticos Ltda. Itapira, SP, Brazil.

${ }^{4}$ Vetnil Indústria e Comércio de Produtos Veterinários Ltda. Louveira, SP, Brazil.

${ }^{5}$ Ouro Fino - Saúde Animal. Cravinhos, SP, Brazil. ${ }^{6}$ GE Healthcare IT Brasil. São Paulo, SP, Brazil.

Declaration of interest. The authors report no conflicts of interest. The authors alone are responsible for the content and writing of the paper.

\section{REFERENCES}

1 Baudendistel L., Goudsouzian N., Cote C.\& Strafford M. 1984. Endtidal CO2 monitoring: Its use in the diagnosis and management of malignant hyperthermia. Anaesthesia. 39(10): 1000-1003.

2 Beck C.A.C., Pippi N.L., Raiser A.G., Brum M.V., Gonçalves G.F., Portella L.C.V., Leme M.C. \& Stedile R. 2004. Ovariectomia em uma cadela com ovários remanescentes: relato de caso. Revista Científica de Medicina Veterinária de Pequenos Animais e Animais de Estimação. 2(5): 15-19.

3 Brun M.V. 2015. Cirurgias do aparelho reprodutor feminino de caninos. In: Brun M.V. (Ed). Videocirurgia em pequenos animais. Rio de Janeiro: Roca, pp.186-213.

4 Detora M. \& Mccarthy R.J. 2011. Ovariohysterectomy versus ovariectomy for elective sterilization of female dogs and cats: is removal of the uterus necessary? Journal of the American Veterinary Medical Association. 239 (11): 14091412.

5 Feranti J.P.S., de Oliveira M.T., de Souza F.W., Hartmann H.F., Baumer S., Soares A.V., Vaz M.A.B., Chaves R.O., Libardoni R.N. \& Brun M.V. 2016. Ovariectomia laparoscópica ou convencional em cadelas: análise hemodinâmica e álgica. Brazilian Journal of Veterinary Medicine. 38(1): 73-78.

6 Ferreira G.S., Franco C.A.D., Santos C.L., Atallah F.A., Estupnañ O.F.T., Silva S.J.Q. \& de Abreu Oliveira A.L. 2013. Ovariectomia laparoscópica em cadelas e gatas. Brazilian Journal of Veterinary Medicine. 35(Supl. 1): 55-60.

7 Freeman L.J. \& Hendrickson D.A. 1998. Minimally invasive surgery of the reproductive system. In: Freeman L.J. \& Hendrickson D.A. (Eds). Veterinary Endosurgery. St. Louis: Mosby, pp.205-217. 
8 Greenfield C.L., Johnson A.L. \& Schaeffer D.J. 2004. Frequency of use of various procedures, skills, and areas of knowledge among veterinarians in private small animal exclusive or predominant practice and proficiency expected of new veterinary school graduates. Journal of the American Veterinary Medical Association. 224(11): 1780-1787.

9 Hafez B. \& Hafez E.S.E. 2004. Anatomia da reprodução feminina. In: Hafez B. \& Hafez E.S.E. (Eds). Reprodução Animal. 7.ed. São Paulo: Manole Ltda, pp.13-39.

10 Hulka J.F., Thweatt D. \& Ulberg L.C. 1973. Contained cautery: studies toward safer laparoscopic sterilization technics. Fertility and sterility. 24(12): 912-920.

11 König H.E. \& Liebich H.G. 2016. Anatomia dos Animais Domésticos: texto e atlas colorido. 6.ed. Porto Alegre: Artmed, 396p.

12 Mayhew P.D. \& Brown D.C. 2007. Comparison of three techniques for ovarian pedicle hemostasis during laparoscopicassisted ovariohysterectomy. Veterinary Surgery. 36(6): 541-547.

13 Normando V.M.F., Brito M.V.H., Araújo Jr. F.A. \& Albuquerque B.C.M. 2004. Repercussões respiratórias do pneumoperitônio induzido em suínos. Acta Cirúrgica Brasileira. 19(6): 664-669.

14 Savassi-Rocha P.R., Ferreira J.T., Diniz M.T. \& Sanches S.R. 1997. Laparoscopic cholecystectomy in Brazil: analysis of 33,563 cases. International surgery. 82(2): 208-213.

15 Schiochet F., Beck C.A.C., Scherer S., Gianotti G.C., Mucillo M.S., Pinto T.M., Contesini E.A. \& Alievi M. 2008. Ovariectomia Laparoscópica em cães com ovários remanescentes: Relato de três casos. In: Anais do $35^{\circ}$ Congresso Brasileiro De Medicina Veterinária - CONBRAVET (Gramado, Brazil). 1 CD ROM.

16 Torres V.N. 2011. Ovariosalpingohisterectomia videolaparoscópica em cadelas: comparação entre os acessos com dois e três portais. 46 f. Porto Alegre, RS. Dissertação (Mestrado em Ciências Veterinárias) - Programa de Pós-graduação em Ciências Veterinárias, Universidade Federal do Rio Grande do Sul.

17 Van Goethem B.E., Rosenweldt K.W. \& Kirpensteijn J. 2003. Monopolar versus bipolar electrocoagulation in canine laparoscopic ovariectomy: a nonrandomized, prospective, clinical trial. Veterinary Surgery. 32 (5): 464-470.

18 Van Goethem B., Schaefers-Okkens A.U.K.E. \& Kirpensteijn J. 2006. Making a rational choice between ovariectomy and ovariohysterectomy in the dog: a discussion of the benefits of either technique. Veterinary Surgery. 35(2): 136-143. 